Images in Medicine

\title{
Parameatal urethral cyst
}

\author{
Lt Col S.C. Shaw ${ }^{a, *}$, Lt Col M.S. Vinod ${ }^{b}$, Col Amit Deugan ${ }^{c}$ \\ ${ }^{a}$ Classified Specialist (Paediatrics) and Neonatologist, Command Hospital (Eastern Command), Kolkata, India \\ ${ }^{\mathrm{b}}$ Classified Specialist (Surgery) and Paediatric Surgeon, Command Hospital (Eastern Command), Kolkata, India \\ ${ }^{\mathrm{c}}$ Senior Advisor \& Head (Paediatrics), Command Hospital (Eastern Command), Kolkata, India
}

\section{A R T I C L E I N F O}

Article history:

Received 13 January 2016

Accepted 12 February 2017

Available online 22 March 2017

Keywords:

Parameatal

Paraurethral

Urethral cyst

\begin{abstract}
A B S T R A C T
Parameatal urethral cyst is a rare clinical entity, resulting in asymptomatic cosmetic concerns, distortion of urinary stream or difficulty in urination. Though they cause considerable parental concerns, natural history is to resolve spontaneously or rarely surgical excision is needed. We report a neonate with asymptomatic parameatal urethral cyst.
\end{abstract}

() 2017 Published by Elsevier B.V. on behalf of Director General, Armed Forces Medical Services.

\section{Introduction}

Parameatal urethral cyst is a rare condition and so far only about 50 cases are described in world literature. ${ }^{1}$ It is a benign cyst and often remains asymptomatic. We report a neonate with parameatal urethral cyst for its rarity and discuss pertinent review of literature.

\section{Clinical and imaging findings}

A term neonate was born to a 27-year-old patient primigravida mother with an uneventful antenatal history and without any history of drug intake other than folic acid, iron and calcium. Neonate was detected to have a small yellowish cystic lesion at tip of penis adjacent to external urethral meatus as visualized in the image (Fig. 1). However the stream and frequency of urine was normal for the neonate. Rest of the genitalia and
USG abdomen was normal. The neonate was discharged with advice to follow up for any urinary difficulty and increase in the size of the lesion.

\section{Discussion}

Parameatal urethral cyst is rare and thought to be formed due to defective process of delamination of foreskin from glans. ${ }^{2}$ Another set of researchers feel it to be due to occlusion of paraurethral duct. ${ }^{3}$ These cysts usually present at birth or in early childhood and usually occur on the ventral or lateral margin of urethral meatus. The diagnosis is made on its clinical appearance. They either remain asymptomatic or are brought to attention due to cosmetic reasons, urinary stream distortion, urinary obstruction or dysuria. Most of the cysts in pediatric population are less than $1 \mathrm{~cm}$ in size and do not cause urinary disturbances. ${ }^{4}$ The differential diagnoses include epidermoid cyst, pilosebaceous cyst, fibroepithelial polyp

\footnotetext{
* Corresponding author.

E-mail address: drscshaw@rediffmail.com (S.C. Shaw).

http://dx.doi.org/10.1016/j.mjafi.2017.02.007

0377-1237/@ 2017 Published by Elsevier B.V. on behalf of Director General, Armed Forces Medical Services.
} 


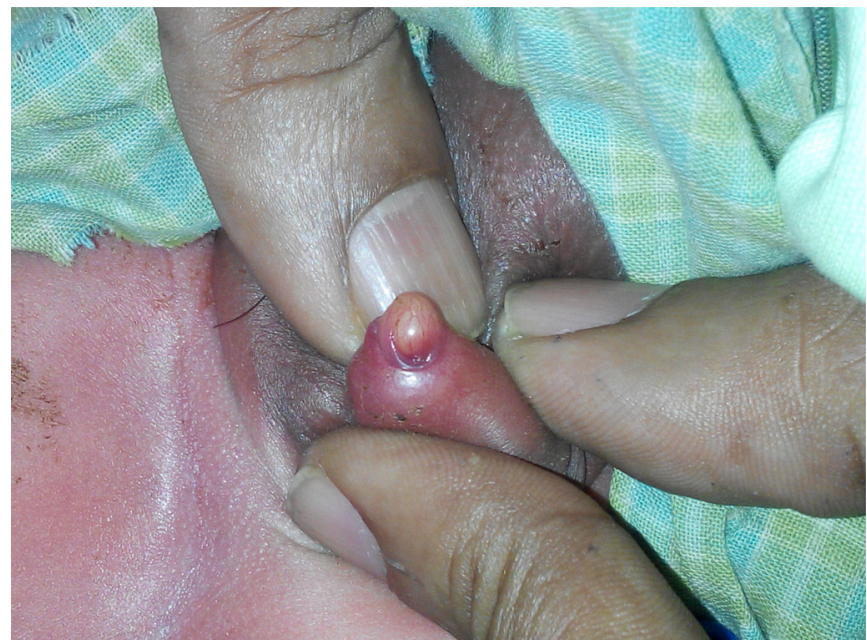

Fig. 1 - Parameatal uretheral cyst at the tip of penis adjacent to external urethral meatus.

and juvenile xanthogranuloma. The treatment modalities range from watchful expectancy for spontaneous resolution to needle aspiration to complete surgical excision. ${ }^{4-7}$ Even spontaneous rupture leading to resolution is known. Marsupialisation leads to unsatisfactory cosmesis. Hence complete surgical excision is the treatment of choice. As our case was an asymptomatic one, we planned to keep him on follow up and to excise surgically in case it causes urinary obstruction or it increases in size.

To conclude, we have presented a rare case of asymptomatic parameatal urethral cyst, who needs to be followed up for any symptoms to develop later in life when it may be subjected to surgical excision.

\section{Conflicts of interest}

The authors have none to declare.

\section{R E F E R E N C E S}

1. Lal S, Agarwal A. Parameatal cyst: a presentation of rare case and review in literature. J Clin Diagn Res. 2013;7(8):1757-1758.

2. Thompson IM, Lantin PM. Parametal cyst of glans penis. J Urol. 1956;76:753-755.

3. Shiraki IW. Parameatal cysts of the glans penis: a report of 9 cases. J Urol. 1975;114:544-548.

4. Kaselas C, Spyridakis I, Patoulias D, Tsioulas P, Patoulias I Parameatal urethral cyst in a newborn - a case report and review of the literature. J Clin Diagn Res. 2016;10(1):SD01-SD02.

5. Onaram M, Tan MO, Camtosun A, Irkilata L, Erdem O, Bozkirli I. Parametal cyst of urethra: a rare congenital anomaly. Int Urol Nephrol. 2006;38:273-274.

6. Sinha AK, Kumar B, Kumar A, Singh MK, Kumar P. Congenital parameatal urethral cyst in male: a case report and review of literature. J Pediatr Surg Case Rep. 2015;3:267-268.

7. Fujimoto T, Suwa T, Ishii N, Kabe K. Paraurethral cyst in female newborn: is surgery always advocated. J Pediatr Surg. 2007;42:400-403. 